\title{
THE INFLUENCE OF ORGANISATIONAL CULTURE OF POLISH COMPANIES ON THEIR COOPERATIVE RELATIONSHIPS
}

\author{
Michał Chomicki*
}

\begin{abstract}
Background. Organisational culture in the context of cooperative relationships is a viable research area. However, based on literature review the influence of organisational culture on these relationships is not a primary research topic of Polish or foreign scientists. Hence, this paper was designed to fill in the identified gap.

Research aims. The aim of this paper is to indicate the relationship between the shape of organisational culture of Polish companies and beneficialness of the shape of cooperative relations between these companies with particular kinds of cooperators. The theoretical part of this article was devoted to identifying the role of cooperative relations in the contemporary economic environment and description of the concept of organisational culture, including its influence on cooperation between companies. The empirical part of this paper was devoted to the description of the conducted research and its results.
\end{abstract}

Methodology. The study was conducted in early 2016 on a random sample of 97 Polish companies, i.e. companies that are based in the Republic of Poland. The survey questionnaire was sent to 493 companies (regardless of size, industry, and geographical region), 114 of which responded with answers. In the process of verification of the consistency of the received responses, 17 of them were rejected due to inaccuracies and other defects. The survey used the respondents' indications of prevailing values in relations with employees, which describe the organisational culture and the indication of the beneficialness of the shape of cooperative relationships with suppliers, customers, and co-opetitors (in the framework of coopetitive relations). The chi-squared independence tests were used to demonstrate the dependencies.

Key findings. In conclusion, it turned out that the key to the beneficial shape of cooperative relationships can be found in the presence of preferred values of flexibility and freedom of action and the orientation of internal affairs. However, the preference of the mentioned values only affects the beneficialness of the shape of the cooperative relations with the customers.

\footnotetext{
*Poznań University of Economics. E-mail: michal.chomicki@ue.poznan.pl
} 
Keywords: organisational culture, inter-organisational relationships, cooperative relationships, beneficialness.

\section{INTRODUCTION}

In today's business environment, well-established cooperative relationships allow for a lasting competitive advantage. The significance of cooperative relationships can be demonstrated by the concept of relational capital in which the surplus value of an enterprise is considered when its estimation by classical valuation methods, both accounting and financial, does not coincide with an objectively perceived total value of such enterprise. It was assumed that the organisation's relations with the elements of the task environment (the relations with the cooperating entities in particular) are, at its basis, of a voluntary nature, so they can be shaped by individual organisations. It was also assumed that the shape of organisational culture influences the shape of cooperative relations, and in consequence the potential benefits associated with it.

\section{Cooperative relationships}

According to the resource paradigm of an organisation, relational resources are important to the functioning of such organisation. The source of these resources are various inter-organisational activities (Wójcik-Karpacz, 2012, p. 22), and inter-organisational relations in particular. These relationships tie organisations and external entities as equal peers. In principle, these peers are suppliers, clients, and competitors, whose importance as actors of horizontal relations has increased over the last few decades (Okada, 2008).

The concept of the organisation's relations with the environment, especially with the elements of the task environment, can refer to two kinds of relationships. Firstly, these bonds can be interactive, which means that they can involve an exchange of resources, including knowledge. Secondly, relationships may be noninteractive when organisations share some common features, such as cognitive systems, value systems (Porac et al., 2002) or identity and strategy derived from isomorphism (Dyer \& Nobeoka, 2000). Interactive relationships with the environment represent relatively durable transactions, flows of 
resources, and other types of connections between the organisation and at least one element from its environment (Oliver, 1990). Such relationships in the light of the resource-based view sum up to relational capital. A particular type of relationships with the environment are inter-organisational relationships, that can be perceived as the outcome of a process in which at least two organisations have formed strong ties and extended their social, economic, and technical services to reduce costs or increase organisational value, and in consequence to obtain mutual benefits (Anderson \& Narus, 1991).

Relationships between companies can be analysed in respect to different areas and from multiple perspectives. C. Lane and R. Bachmann suggested an analysis of relationships at three levels - interpersonal, organisational, and institutional (Lane \& Bachmann, 1997). The core of a relationship can be based on interpersonal contacts, contracts or membership in associations uniting organisations that are present in a given sector - these are called institutional relationships.

Contract-based relationships have the greatest importance for an organisation's activities, as contracts are the basic instrument for regulating business. Agreements between cooperators can be broken down according to the area of the contract-based regulations. This way a few different kinds of contracts can be distinguished, including development, purchasing, production, marketing, and distribution agreements (Urban \& Vendemini, 1992, p. 131). The extent to which the given areas are regulated by the agreements can thus be considered as a measure of the interconnection of the partners. These relationships are generally formed by a manifestation of the will of cooperation. The cooperative relationships can be divided into arm's length contractual relations, which do not form an implicit long-term commitment, and obligational relations that impose such an obligation. The criteria that differentiate these two types of relationships are interdependence and time span for reciprocity (Sako, 1992, p. 4).

Considering the above remarks on the perception of relationships, it is necessary to adopt a definition according to which the cooperative relationships form vertical or horizontal ties between cooperators (i.e. an organisation and its suppliers, customers, and cooperating competitors), maintaining the repetitive flows of tangible and intangible resources to obtain mutually satisfying benefits.

The dynamics of the contemporary business environment justify the need to have a broader look at interactions between organisations. 
These entities do not limit their actions to the analysis of their relationships only in the context of inter-organisational relationships, but more often they consider the dynamics of network structures in which they participate. According to M. Ebers (1997), inter-organisational networks can be defined as certain bonds that establish repetitive, partner-specific relationships based on an exchange of a definite (often determined as a moment of reaching a common goal or desire to terminate a relationship for another reason) or an indefinite period between a finite number of business actors. These actors maintain individual control over their resources, but in some cases, they also negotiate or co-ordinate their use. This is different from the market as a structure of resources allocation, where one-sided coordination of plans and actions is preferred. In addition, as a part of business networks, participants communicate a wider range of information to each other than in the case of separate market exchanges. Inter-organisational networks differ from hierarchy (enterprise), understood as a structure of resource allocation, primarily because their participants do not create a new economic entity, and thus maintain a unilateral control over their own resources. B.R. Barringer and J.S. Harrison (2000, p. 387) presented a concept in which inter-organisational networks are constellations of enterprises more often organised with social contracts as underlying bonds, rather than legally binding contracts as a foundation. According to the authors of this concept, a network is a separate form of cooperation alongside other ways of allocating resources (i.e. market and hierarchy). It should be noted, however, that in the networks themselves there are different forms of cooperation between the participants, so that the relationship between the network and the different types of cooperation (relations) can be treated as analogous to the relation of the whole to a part.

T. Ritter, I.F. Wilkinson, and W.J. Johnston (2004, p. 179) made a clear distinction between the term of inter-organisational relations and a business network by describing inter-organisational relationships as components of business networks. The authors described five levels of a business activity, from the level of independent actions of individual actors to complex network links between them. Independent actors conduct business activities without entering relationships with other entities. Two-sided relationships (diads) are the relationships between two different actors. A relationship portfolio is a situation in which individual actors are linked by relationships to more participants. The 
level of interrelated relationships presents the configuration of the actor's relations and the relationships in which the participants of its relationship portfolio remain. At business network level, the analysis is made of all relationships between the elements of a given population. As it can be seen, the primary object of analysis in inter-organisational relationships are the relationships between two entities (diads).

E. Urbanowska-Sojkin (2003, p. 126) distinguished twelve types of co-operation links between enterprises and arranged a proposal for the gap between the market and the hierarchy, ranking them in order from the lowest to the highest level of cooperation: trade, information exchange, R\&D assistance, technical assistance, leasing, co-production, franchising, consortium, joint venture, buyout, and merger. This concept rightly does not consider the structure of inter-organisational networks as a separate category. This can be explained on the one hand by its elusive character of inter-organisational relations, and on the other by their high degree of flexibility - for example, both joint ventures and R\&D assistance are elements of inter-organisational networks. Thus E. Urbanowska-Sojkin presented various types of relationships that are elements of inter-organisational networks.

D. Latusek-Jurczak (2014) presented a breakdown of forms of cooperation with co-operators based on two criteria. The first criterion of the division was the coordination mechanisms of relations and as a second criterion she chose the motivation to enter business relationships, among which she pointed out the benefits of standardisation, the benefits of diversity, and the collaborative acquisition of knowledge. However, this is not an exhaustive catalogue of motives for undertaking inter-organisational co-operation, although the author undoubtedly pointed out the most important values of the selected criteria. Especially important is the motive of the joint acquisition of knowledge by the parties of the relationship.

\section{Organisational culture and inter-organisational relationships}

The literature review makes it possible to conclude that research on organisational culture within the framework of cooperative relations, its influence on relations and its transfer between parties of the relationships, is not the primary subject for both Polish and foreign researchers. In the literature on the subject, it is indicated that some 
forms of inter-organisational relations (in the marketing terminology known as the B2B relations), at the basis of market orientation - offering a product which answers the needs of current and potential clients can be described as elements of philosophy or culture by themselves (Narver \& Slater, 1990, 1995), although the impact of organisational culture on these relationships is not identified and moreover, its nature is not indicated. On the other hand, Polish researchers emphasise the influence of organisational culture on relationships, especially with customers (Król \& Ludwiczyński, 2006, p. 131), but they also do not point to its essence. Considering the above observations, it should be recognised that the shape of organisational culture potentially has a significant impact on the usefulness of the shape of cooperative relations, even if it is not thoroughly investigated. Consequently, to better illustrate the impact of the study, it is necessary to clarify the concept of organisational culture and to indicate the characteristics that should be examined.

Culture is an element of the context of any organisation's activities, including partners operating in a cooperative relationship. The nature and essence of culture, especially due to its wide influence and the conditioning of various phenomena and activities, may seem elusive. According to S. Czarnowski (1948, p. 16) the term "culture" means common good and collective legacy, the fruit of the creative and transformative effort of countless generations. The meaning of this definition is also maintained in contemporary descriptions of the term "culture". Culture meant this way can be identified and attributed to nations or so-called cultural circles (Sułkowski, 2012, p. 128) and organisations in which it is a derivative of national culture (Hofstede, 1980). G. Hofstede (1980) distinguished four dimensions of a national culture: 1) distance of power, 2) individualism (as opposed to collectivism), 3) masculinity (as opposed to femininity), 4) avoidance of uncertainty. Over time, in later studies, the model was enriched with two additional dimensions: 1) long-term orientation (Hofstede \& Bond, 1988) and 2) restraint (Hofstede et al., 2011). Another approach to the dimensions of culture was presented by E.T. Hall (1976) who claimed that culture can be either: 1) mono or polychronic, 2) high or low context in communication, 3) contact culture or culture of spatial distance. G. Hofstede's model has been extended to GLOBE culture research (House et al., 2004), and includes the following dimensions: 1) avoiding uncertainty, 2) distance of power, 3) social emphasis on 
collectivism (institutional collectivism), 4) family collectivism (group collectivism), 5) gender equality, 6) assertiveness, 7) orientation on the future, 8) performance orientation, 9) orientation on people. These models show the complexity of culture as an environment in which people live and work. The concepts of characterising organisational culture presented above seem to attach too much importance to the characteristics of culture, which may not necessarily influence the beneficialness of the shape of cooperative relations. Therefore, it was decided to analyse the organisational culture of the surveyed companies using the concept of competing values developed by K. Cameron and R. Quinn (2015), because the characteristics of organisational culture, according to their model, are more synthetic. The authors proposed to characterise the organisational culture using two pairs of competing values: 1) stability and control, as opposed to flexibility and freedom of action, 2) orientation on the environment and diversity of work of employees and their groups, as opposed to orientation on internal affairs and integration of employees and their groups. For the purpose of this study, it was decided to modify the model - the second pair of competing values was split into two new pairs of values: 1) integration of employees and their groups, and the differentiation between employees and their groups, 2) orientation on an environment and orientation on internal affairs.

\section{The influence of organisational culture on the shape of cooperative relations - presentation of research results}

To identify the relationship between the organisational culture and the shape of cooperative relations, it was decided to adopt several assumptions related to the measures that were used. Organisational culture, as presented before, has been described by the indication to the overwhelming presence of competing values proposed by K. Cameron and R. Quinn (2015), which underwent some minor modifications (the third pair of competing values was distinguished). Due to the equifinal character of the relationship maintenance process, the description of the shape of cooperative relations is based on the level of beneficialness of the shape of relations with different types of co-operators. It should be noted that none of the respondents pointed to unbeneficially or highly unbeneficially shaped relations with recipients, which can be explained by the fact that the mere existence of relations with 
customers can be perceived by respondents as a sufficient condition for their beneficialness. The beneficialness in this case is understood as the difference between the effects of a given relationship and the costs associated with it.

The study was conducted in early 2016 on a sample of 97 Polish companies, i.e. companies that are based in the Republic of Poland. The survey questionnaire was sent to 493 companies (regardless of size, industry, and geographical region), 114 of which responded with answers. In the process of verification of the consistency of the received responses, 17 of them were rejected due to inaccuracies and other defects.

Firstly, the collation of values of the chi-square independence tests between the characteristics describing organisational culture and the beneficialness of the shape of cooperative relations was presented in Table 1.

Table 1. Collation of chi-squared independence tests values between the characteristics describing the preferred state in relations with employees and the beneficialness of the shape of cooperative relations of the examined enterprises

\begin{tabular}{|l|c|c|c|}
\hline \multirow{2}{*}{} & \multicolumn{3}{|c|}{$\begin{array}{r}\text { The beneficialness of the shape of } \\
\text { cooperative relations with }\end{array}$} \\
\cline { 2 - 4 } & suppliers & customers & coopetitors \\
\hline $\begin{array}{l}\text { Level of plenipotency } \\
\text { (Stability and control - flexibility and freedom } \\
\text { of action) }\end{array}$ & $\begin{array}{c}.41 \\
.8152)\end{array}$ & $\begin{array}{c}7.23^{*} \\
(.0072)\end{array}$ & $\begin{array}{c}.64 \\
(.7251)\end{array}$ \\
\hline $\begin{array}{l}\text { The nature of employee activities } \\
\text { (Integration of employees and their groups - } \\
\text { differentiation between employees and their } \\
\text { groups) }\end{array}$ & $\begin{array}{c}.50 \\
(.7782)\end{array}$ & $\begin{array}{c}3.46 \\
(.0628)\end{array}$ & $\begin{array}{c}.42 \\
(.8096)\end{array}$ \\
\hline $\begin{array}{l}\text { Orientation } \\
\text { (Orientation on the environment - orientation } \\
\text { on internal affairs) }\end{array}$ & $\begin{array}{c}3.79 \\
(.1506)\end{array}$ & $\begin{array}{c}6.04^{*} \\
(.0140)\end{array}$ & $\begin{array}{c}4.00 \\
(.1355)\end{array}$ \\
\hline
\end{tabular}

Note: The statistically significant chi-squared independence test scores (with a standard significance level of .05) were bolded and marked with asterisks $\left({ }^{*}\right)$.

Source: own study based on empirical research.

By analysing the data presented in Table 1, it should be noted that only the preferred states within the areas of two characteristics (the level of plenipotency and orientation) have impact on the beneficialness of the shape of the cooperative relations. In addition, this impact only 
concerns cooperative relationships with customers. It should also be noted that the preferred state in the area of the third characteristics type - relations with employees (the nature of employees' actions) affects this type of relationships, although it is irrelevant at the significance level of .05, but the $p$ value in this case is relatively low (.0628). For better visualisation of the nature of the identified, significant relationships, they are presented in Charts 1 and 2.

The chart below shows the structure of answers about the preferred state in the relationships with employees (stability and control or flexibility and freedom of action), depending on the beneficialness of the relationships with customers.

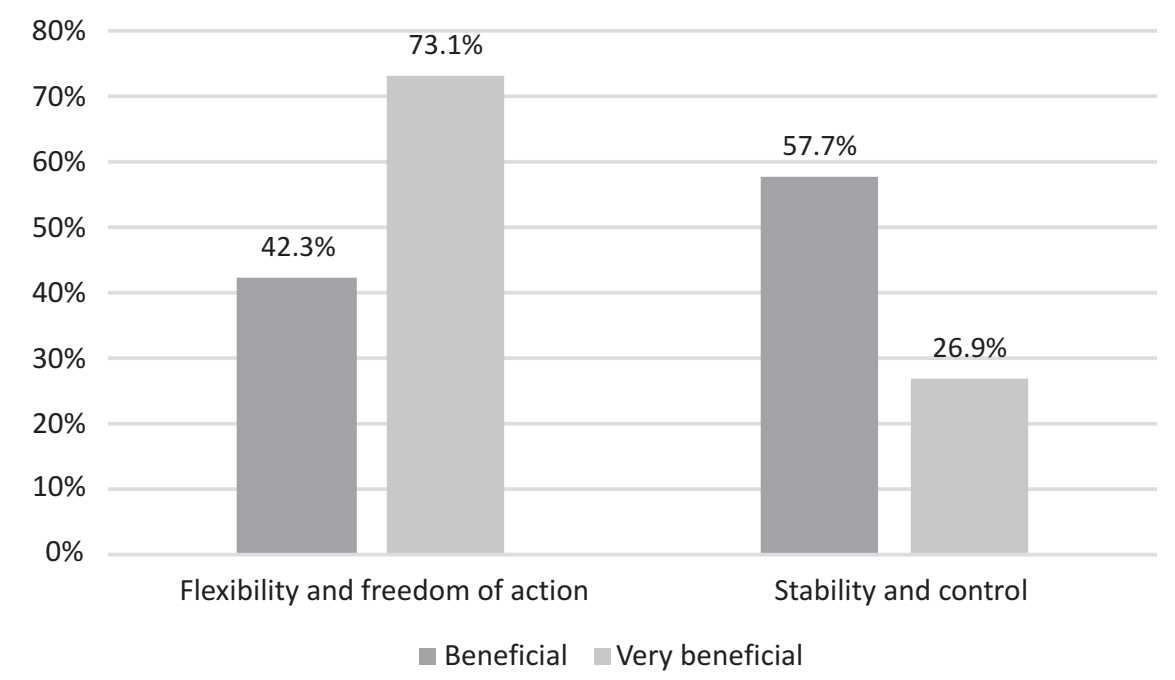

Chart 1. Preferred state in relations with employees (stability and control or flexibility and freedom of action) depending on the beneficialness of the shape of cooperative relations with customers

Source: own study based on empirical research.

An observation of the responses structure presented in the chart shows that companies with very beneficially shaped cooperative relationships with customers more often indicate flexibility and freedom of action as a preferred state in relations with employees, and less often indicate stability and control than enterprises with beneficially shaped cooperative relationships with their customers. The above statement allows concluding that there is a pattern of increasing relationships beneficialness in case of relationships with 
customers with increasing share of responses that the more preferred value describing organisational culture is flexibility and freedom of action. This dependence can be explained by the need to continually adapt to the changing environment, especially to the evolving cooperative relationships. Peacefulness, understanding, forbearance, and adaptability of employees are conducive to the creativity and solving of nonstandard problems, allowing the cooperative relationships with customers to be shaped beneficially.

The chart below shows the structure of responses regarding the preferred state in relations with employees (orientation on position in the environment or orientation on internal affairs), depending on the beneficialness of the cooperative relations with customers.

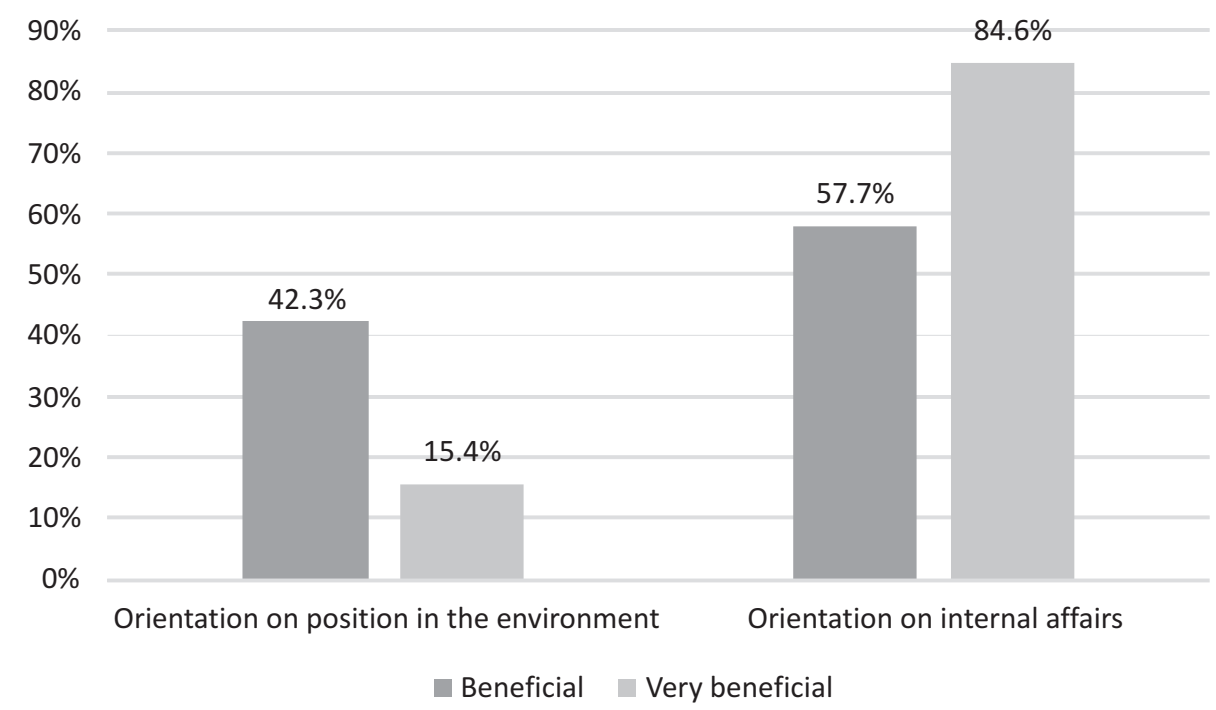

Chart 2. Preferred state in relations with employees (orientation on internal affairs or orientation on the position in the environment) depending on the beneficialness of the shape of cooperative relations with customers.

Source: own study based on empirical research.

The above chart shows that companies with very beneficially shaped cooperative relationships with customers more often indicate that they are oriented on internal affairs as a preferred state in their relationships with employees, and less often indicate their position in the environment than companies with beneficially shaped cooperative relationships with customers. It can therefore be stated that there is 
a pattern of increasing beneficialness of the shape of cooperative relations with customers as the share of responses indicating orientation on internal affairs as a preferred state increases. This conclusion is interesting because intuitively one would suppose that the orientation on the position in the environment as the preferred state affects the beneficialness of the shape of the cooperative relations. This observation can be explained by the fact that the orientation on internal affairs fosters continuous improvement of productivity and performance, which in turn translates into the beneficial shape of cooperative relations with customers.

\section{CONCLUSIONS AND SUMMARY}

The results presented in this study indicate that organisational culture influences the beneficialness of the shape of cooperative relations. However, this effect is limited only to the shape of cooperative relationships with customers, which is generally consistent with the results of the aforementioned studies. The uniqueness of the identified relationships between preferred states describing organisational culture and the beneficialness of the shape of cooperative relationships with customers in the absence of similar dependencies with other types of co-operators should be justified by the specificity of relationships between organisations and their customers. These relationships, from the reference point of the surveyed organisations, follow the course of the value chain (supplier $\rightarrow$ referential organisation $\rightarrow$ customer). Based on that it can be stated, that the elements that make up organisational culture also influence the beneficialness of the shape of cooperative relations according to the course of the supply chain. This means that customers are susceptible to the impact of values shared by their suppliers' employees, as well as the broadly defined working environment of their workgroups, that allow them to achieve beneficial customer relationships by those suppliers.

On the other hand, it should be noted that the flexibility and freedom of action allow for a high level of adaptation of the supplier's employees and make solving non-standard problems easier. It should also be noted that the orientation on internal affairs, as opposed to the orientation on the position in the environment, influences the beneficialness of the shape of cooperative relations with customers. This observation may 
be explained by the fact that performance, as a value implied by the orientation on internal affairs, allows to maintain the highest possible quality or the lowest possible costs, which in consequence translates into beneficial relationships with customers.

\section{REFERENCES}

Anderson, J.C. \& Narus, J.C. (1991). A model of the distributor's perspective of distributor-manufacturer working relationships. Journal of Marketing, $48,4$.

Barringer, B.R. \& Harrison, J.S. (2000). Walking a tightrope: creating value through interorganizational relationships. Journal of Management, 26, 3.

Cameron, K.S. \& Quinn, R.E. (2015). Kultura organizacyjna-diagnoza i zmiana: model wartości konkurujacych. Warszawa: Wolters Kluwer.

Czarnowski, S. (1948). Kultura, Warszawa: Spółdzielnia Wydawnicza „Książka”.

Dyer, J.H. \& Nobeoka, K. (2000). Creating and managing a high performance knowledge-sharing network: The Toyota case. Strategic Management Journal, 21.

Ebers, M. (1997). Explaining inter-organizational network formation. The Formation of Inter-Organizational Networks, 1.

Hall, E.T. (1976). Beyond Culture. Anchor. New York: Anchor Books.

Hofstede, G. (1980). Culture's Consequences: International Differences in Work-Related Values. Beverly Hills, CA: Sage.

Hofstede, G. \& Bond, M.H. (1988). The Confucius connection: from cultural roots to economic growth. Organizational Dynamics, 16.

Hofstede, G., Hofstede, G.J. \& Minkov, M. (2011). Kultury i organizacje: zaprogramowanie umystu. Warszawa: Polskie Wydawnictwo Ekonomiczne.

House, R.J., Hanges, P.J., Javidan, M., Dorfman, P.W. \& Gupta, V. (eds.) (2004). Culture, Leadership, and Organizations: The GLOBE Study of 62 Societies. Thousand Oaks, CA: Sage.

Król, H. \& Ludwiczyński, A. (2006). Zarzqdzanie zasobami ludzkimi. Warszawa: Wydawnictwo Naukowe PWN.

Lane, C. \& Bachmann, R. (1997). Cooperation in inter-firm relations in Britain and Germany: the role of social institutions. British Journal of Sociology, 2(48).

Latusek-Jurczak, D. (2014). Sieci międzyorganizacyjne jako struktury współpracy podstawowe pojęcia analityczne. In: A.K. Koźmiński \& D. Latusek-Jurczak (eds.), Relacje międzyorganizacyjne w naukach o zarzadzaniu. Warszawa: Wolters Kluwer.

Narver, J.C. \& Slater, S.F. (1990). The effect of a market orientation on business profitability. Journal of Marketing, 54(10). 
Okada, Y. (2008). From vertical to horizontal inter-firm cooperation: Dynamic innovation in Japan's Semiconductor Industry. Asia Pacific Business Review, 3(14).

Oliver, Ch. (1990). Determinants of Interorganizational Relationships: Integration and Future Directions. Academy of Management Review, 15, 2.

Porac, J.F., Ventresca, M.J. \& Mishina, Y. (2002). Interorganizational cognition and interpretation. In: J.A.C. Baum (ed.), Companion to Organizations, Wiley-Blackwell.

Ritter, T., Wilkinson, I.F. \& Johnston, W.J. (2004). Managing in complex business networks. Industrial Marketing Management, 33.

Sako, M. (1992). Prices, Quality and Trust: Inter-firm Relations in Britain and Japan. Cambridge: Cambridge University Press.

Slater, S.F. \& Narver, J.C. (1995). Market orientation and the learning organisation. Journal of Marketing, 59(3).

Sułkowski, Ł. (2012). Kulturowe procesy zarzadzania. Warszawa: Difin.

Urban, S. \& Vendemini, S. (1992). European strategic alliances. Co-operative corporate strategies in the New Europe. Oxford: Blackwell Business.

Urbanowska-Sojkin, E. (2003). Zarzadzanie przedsiębiorstwem. Od kryzysu do sukcesu. Poznań: Wydawnictwo Akademii Ekonomicznej.

Wójcik-Karpacz, A. (2012). Zdolność relacyjna w tworzeniu efektów współdziałania matych i średnich przedsiębiorstw. Warszawa: Oficyna Wydawnicza SGH. 


\section{WPKYW KULTURY ORGANIZACYJNEJ POLSKICH PRZEDSIĘBIORSTW NA UKSZTAŁTOWANIE ICH RELACJI KOOPERACYJNYCH}

\section{Streszczenie}

Tło badań. Kultura organizacyjna w kontekście relacji kooperacyjnych jest istotnym obszarem badawczym. Jednakże, opierajac się na przeglądzie literatury, można stwierdzić, że wpływ kultury organizacyjnej na te relacje nie jest głównym tematem badawczym polskich lub zagranicznych naukowców. W związku z tym niniejszy artykuł stanowi próbę wypełnienia zidentyfikowanej luki.

Cel badań. Celem tego artykułu jest wskazanie związku pomiędzy ukształtowaniem kultury organizacyjnej polskich przedsiębiorstw a korzystnością ukształtowania relacji kooperacyjnych między tymi przedsiębiorstwami oraz ich poszczególnymi rodzajami kooperantów. Część teoretyczna została poświęcona identyfikacji roli powiązań kooperacyjnych we współczesnym otoczeniu gospodarczym oraz określeniu pojęcia kultury organizacyjnej, w tym jej wpływu na relacje kooperacyjne między firmami. Część empiryczna została poświęcona opisowi przeprowadzonych badań i ich wyników.

Metodologia. Badanie zostało przeprowadzone na początku 2016 r. na losowej próbie 97 polskich przedsiębiorstw, tj. firm mających siedzibę w Rzeczpospolitej Polskiej. Kwestionariusz ankiety został przesłany do 493 firm (niezależnie od wielkości, branży i regionu geograficznego), z których 114 go wypełniło. W procesie weryfikacji spójności otrzymanych odpowiedzi 17 z nich zostało odrzuconych z powodu niedokładności i innych wad. W badaniu wykorzystano wskazania respondentów o przeważających wartościach w relacjach z pracownikami, które opisują kulturę organizacyjna, oraz wskazania na poziom korzystności ukształtowania relacji kooperacyjnych z dostawcami, odbiorcami i konkurentami (w ramach relacji koopetycyjnych). Testy niezależności chi-kwadrat wykorzystano do przedstawienia zidentyfikowanych zależności.

Kluczowe wnioski. W wyniku przeprowadzonego postępowania badawczego stwierdzono, że kluczem do korzystnego ukształtowania stosunków kooperacyjnych jest obecność w przedsiębiorstwie wartości elastyczności i swobody działania oraz ukierunkowanie na sprawy wewnętrzne. Należy jednak podkreślić, że występowanie wspomnianych wartości wpływa jedynie na korzystne ukształtowanie stosunków kooperacyjnych z klientami.

Słowa kluczowe: kultura organizacyjna, relacje międzyorganizacyjne, relacje kooperacyjne, korzystność. 